\title{
A Low-Cost Indigenous Intervention which has Revolutionized the Drilling Technology and Changed the Life of Millions of Farmers in the State of Uttar Pradesh, India
}

\author{
Pratik Ranjan Chaurasia ${ }^{1}()_{0} \cdot$ Subhash $^{2}$
}

Received: 12 March 2017 / Accepted: 4 February 2018/Published online: 23 February 2018

(C) The Institution of Engineers (India) 2018

\begin{abstract}
An unknown indigenous driller combined the percussion and circulation drilling principles, resulting in the development of low cost, low weight manual boring set in the year 1990-1991/1991-1992, which revolutionized the shallow well drilling technology and made possible to drill about 4.5 million shallow bore wells in the State. This has changed the landscape of irrigated agriculture, changing the life of millions of small and marginal farmers and contributed a lot in increasing crop production and crop productivity. The developed drilling equipment locally known as "Pressure Boring Set" is manually operated, low cost and can be transported on bicycles. Drilling cost is also less. This low cost and simple technology made it possible to drill large number of shallow bore wells in comparatively short time span and less cost, consequently enhancing the rate of increase in irrigated area and in turn crop production and productivity. Cost of the boring set is also low, as compared to traditional sand pump hand boring set and suitable for alluvial areas.
\end{abstract}

Keywords Shallow well drilling · Drilling technology · Percussion and circulatory drilling - Manual boring set . Irrigated area

Pratik Ranjan Chaurasia

pratikcranjan@gmail.com

1 Minor Irrigation Department, Government of Uttar Pradesh, Lucknow, India

2 Department of Minor Irrigation, Government of Uttar Pradesh, Lucknow, India

\section{Introduction}

Irrigation is the spirit of agriculture and it is one of the most important engineering interventions and inputs, which increases agricultural productivity and production. Assured irrigation practices encourage the farmers to invest more on inputs like fertilizers, high yielding seeds, pesticides, etc. Moreover, an own water source increases the confidence of a farmer as he can irrigate the land as and when required. In this context, bore well irrigation is an important intervention in increasing agricultural productivity.

Uttar Pradesh, the most populous and one of the largest State of India, has potential groundwater resource. The use of this resource was perceived way back in early eighties to benefit millions of small and marginal farmers of the state. Presently, there are 23.325 million land holdings in the state, out of which $90 \%$ are small and marginal with an area of less than 2 hectares [1]. One of the innovative approaches to benefit these small and marginal farmers was the adaption of any low-cost technology for drilling bore well. In this context, the Minor Irrigation Department of Uttar Pradesh, India had started the free boring scheme in alluvial formations of the state in the year 1984. The mandate of the scheme was to drill shallow bores up to an average depth of $20 \mathrm{~m}$ with a financial assistance of INR $3000 /$ - per boring [2]. The prevalent drilling technology at that time was sand pump boring set which was very slow, heavy and costly to operate. The invention of an indigenous boring technology (locally named as "Pressure Boring Set") in year 1990 revolutionized the shallow well drilling technology in alluvial formations. The state has witnessed the drilling of about 4.5 million shallow bore wells in the last three and half decades after adapting this indigenous technology [3]. The mass adaption of this 
technology further refined it and presently, is the most widely used technique to drill shallow bores in the state.

\section{Invented Technology}

The three essential bore well drilling functions are: (1) smooth penetration through subsurface formations: (2) removal of drill cuttings: and (3) preventing the cave-in of the bore until the lowering of well assembly. In order to fulfill these three core functions, percussion and rotary drilling technologies have been developed [4, 5]. An unknown indigenous driller innovatively combined the principles of these two technologies to develop a low-cost and light manual boring set through which drilling has become very fast compared to the traditional sand pump boring set. The weight of the equipment is so low that it can be transported even on a bicycle.

\section{Principle and Components of Drilling Equipment}

The mechanism to penetrate the subsurface formation is based on shearing and cutting action as employed in percussion drilling. On the other hand, the mechanism to remove the formation cuttings and to control the borehole from cave-in during drilling is based on the principles of rotary drilling, where formation cuttings are removed by the circulation of drilling fluid through drill pipe/borehole while the bore is protected from collapsing by hydrostatic pressure maintained during drilling [6]. This drilling equipment includes

a. Two wooden $\operatorname{logs}$ as columns of the frame (each $1500 \mathrm{~mm}$ long) to support operating arm.

b. One iron rod to act as beam of the frame $(1500 \mathrm{~mm}$ long).

c. One wooden $\log$ to act as operating shaft/arm (3000-4000 mm long).

d. GI pipes of size 50/65 mm (no. depends on the depth of drilling).

e. GI socket of size $75 \mathrm{~mm}$ (with a provision to attach with drill stem or pipe) to function as cutting shoe.

f. L-shape clamp to hinge the operating arm with drill stem/pipe.

g. Labor for operating the set up (no. depends on the depth of drilling).

As shown in Fig. 1, about 4-6 laborers move the operating arm up and down; giving reciprocating motion to the drill pipe; which is hinged to the operating arm at the end by L-shape iron clamp. One man stands on two columns of the frame and keeps his palm on drill pipe/stem and moves his palm up and down with the motion of operating arm to function as a suction valve. Here, the principle of reciprocating pump comes into action that lifts the drilling fluid

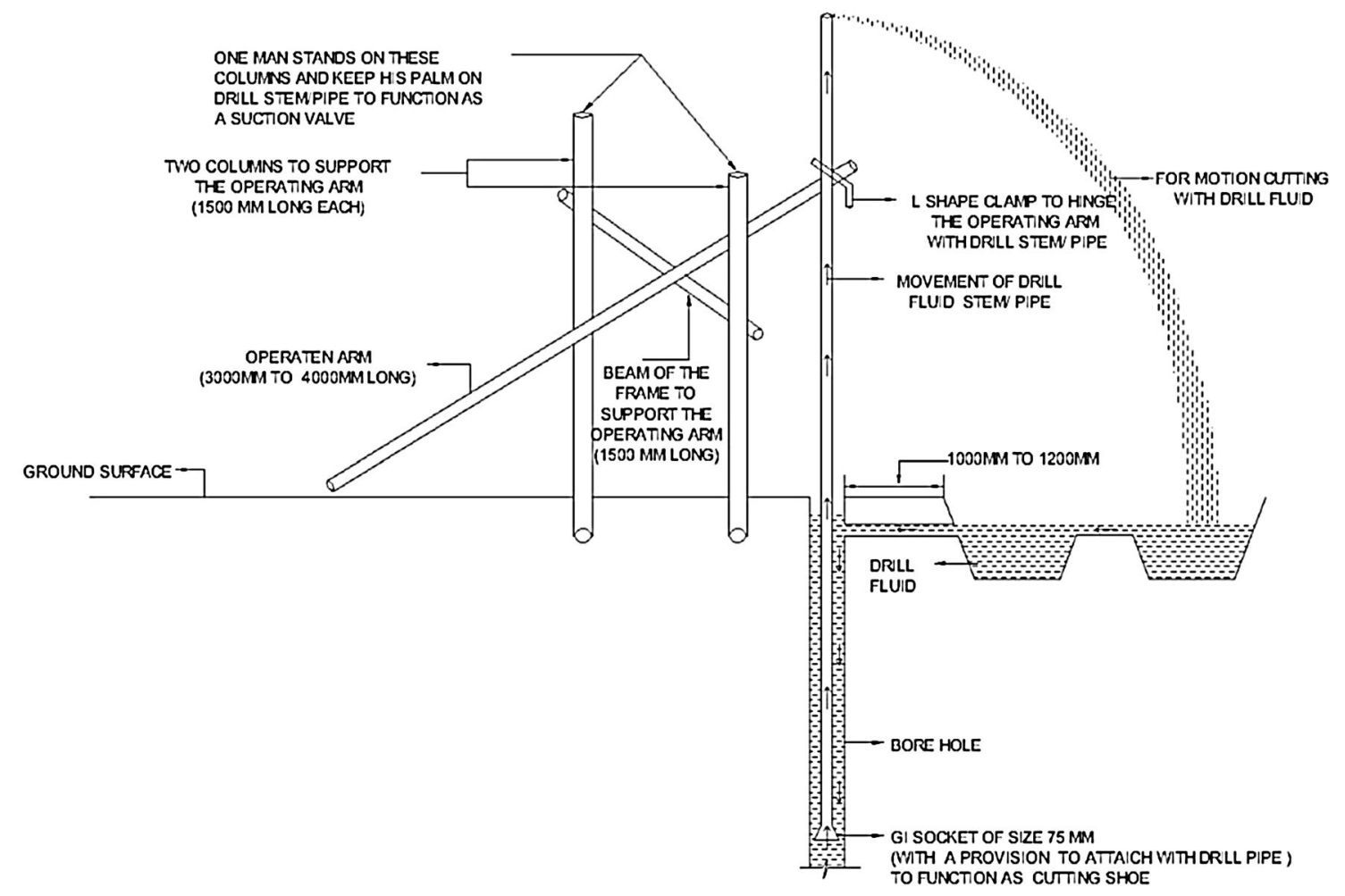

Fig. 1 Operational diagram of the drilling equipment 
Table 1 Cost of boring for strainer well using indigenous technology [7] (financial year 2016-2017)

\begin{tabular}{|c|c|c|c|c|c|}
\hline S. no. & Details of work & Unit & Qty & Rate (INR) & Amount (INR) \\
\hline 1 & Excavation of $2.0 \mathrm{~m}$ diameter pit & & & & \\
\hline $\mathrm{a}$ & From ground surface to $1.5 \mathrm{~m}$ depth & $\mathrm{m}^{3}$ & 4.71 & 82.00 & 386.22 \\
\hline $\mathrm{b}$ & From 1.5 to $3.0 \mathrm{~m}$ depth & $\mathrm{m}^{3}$ & 4.71 & 95.50 & 449.81 \\
\hline \multicolumn{2}{|c|}{ Total (A) } & & & & 836.03 \\
\hline 2 & Carting of boring set & Job & 1 & 300.00 & 300.00 \\
\hline 3 & Drilling charges & $\mathrm{m}$ & 30 & 307.15 & 9214.50 \\
\hline \multicolumn{2}{|c|}{ Total (B) } & & & & 9514.50 \\
\hline 4 & Materials detail & & & & \\
\hline a & $110 \mathrm{~mm}$ PVC pipe $\left(6 \mathrm{Kgf} / \mathrm{cm}^{2}\right)$ & $\mathrm{m}$ & 15 & 149.00 & 2235.00 \\
\hline $\mathrm{b}$ & $110 \mathrm{~mm}$ PVC strainer pipe $\left(6 \mathrm{Kgf} / \mathrm{cm}^{2}\right)$ & $\mathrm{m}$ & 15 & 146.00 & 2190.00 \\
\hline $\mathrm{c}$ & 110 mm PVC end cap & Unit & 1 & 48.00 & 48.00 \\
\hline d & $110 \mathrm{~mm}$ FTP with cast iron flange & Unit & 3 & 120.00 & 360.00 \\
\hline $\mathrm{e}$ & Solvent cement & 1 & 0.18 & 144.00 & 25.92 \\
\hline $\mathrm{f}$ & $100 \mathrm{~mm}$ reflux valve non ISI & Unit & 1 & 1140.00 & 1140.00 \\
\hline $\mathrm{g}$ & $1.25-1.30 \mathrm{~mm}$ mesh size filter cloth & $\mathrm{m}$ & 15 & 12.00 & 180.00 \\
\hline $\mathrm{h}$ & 500 micron mesh size filter cloth & $\mathrm{m}$ & 15 & 10.00 & 150.00 \\
\hline $\mathrm{i}$ & $5 \mathrm{~mm}$ diameter nylon dori (rope) & $\mathrm{m}$ & 100 & 1.32 & 132.00 \\
\hline $\mathrm{j}$ & $100 \mathrm{~mm}$ cast iron bend & Unit & 1 & 510.00 & 510.00 \\
\hline $\mathrm{k}$ & 110 mm PVC coupler & Unit & 3 & 43.00 & 129.00 \\
\hline \multicolumn{2}{|c|}{ Total $(\mathrm{C})$} & & & & 7099.92 \\
\hline 5 & Pumping test (diesel pump set charges) & $\mathrm{h}$ & 10 & 110.00 & 1100.00 \\
\hline \multicolumn{2}{|c|}{ Total (D) } & & & & 1100.00 \\
\hline \multicolumn{3}{|c|}{ Total $(\mathrm{A}+\mathrm{B}+\mathrm{C}+\mathrm{D})$} & & & $18,550.45$ \\
\hline 6 & Contingency ( $2 \%$ of total) & 371.01 & & & \\
\hline \multicolumn{2}{|c|}{ Grand total (INR) } & & & & $18,921.45$ \\
\hline \multicolumn{2}{|c|}{ SAY (INR) } & & & & $18,900.00$ \\
\hline
\end{tabular}

from the bottom of bore and conveyed it to out of drill pipe. The moving column of drilling fluid through the drill pipe also lifts the drill cuttings in suspension mode to the surface. The driller guides the discharging fluid to settling pit with the help of his hands. The reciprocating motion of the drill stem/pipe cut the formation by shearing and cutting action. Formation cuttings are then move with the drill fluid and come out of the top of the drill pipe and the laborer standing on the columns with his palm on drill pipe guides the circulating fluid to the settling pit. In this technology, the percussion principle is used to cut the subsurface formations while the rotary principle is used to remove the formation cuttings and control the borehole from cave-in by hydrostatic pressure maintained during the drilling operation. Usually, clay mixed with water is used as the drilling fluid. The system is a combination of percussion and reverse circulation rotary drilling. As drilling operation proceeds another length of drill pipe is screwed and the clamp is shifted upward.

This drilling set is very light and can be transported even on a bicycle. The cost of drilling is only about INR 307.15 per meter in alluvial formation. The technique is well adapted for drilling shallow bores up to the depth of $30 \mathrm{~m}$. Though, it is feasible to drill bores up to a depth of $60 \mathrm{~m}$; however, to keep the drilled bore straight is a challenge for the driller. The cost of a $110 \mathrm{~mm}, 30 \mathrm{~m}$ deep strainer and cavity boring through this technology is presented in Tables 1 and 2 [7].

\section{Impact of Innovative Technology}

During the launch of free boring scheme in the year 1984, the major challenge was to install a large number of bore wells at low-cost as there was pressing need to increase irrigation facilities to increase agricultural production.

Initially, an assistance of only INR 3000/ per boring was provided, which has been revised many times since its inception. At present, the pattern of assistance under the scheme is as given in Table 3 [2]:

Under the scheme, the Department of Minor Irrigation of the Government of Uttar Pradesh, India constructs the 
Table 2 Cost of boring for installing cavity well using indigenous technology [6] (financial year 2016-2017)

\begin{tabular}{|c|c|c|c|c|c|}
\hline S. no. & Details of work & Unit & Qty & Rate (INR) & Amount (INR) \\
\hline 1 & Excavation of $2.0 \mathrm{~m}$ diameter pit & & & & \\
\hline a & From ground surface to $1.5 \mathrm{~m}$ depth & $\mathrm{m}^{3}$ & 4.71 & 82.00 & 386.22 \\
\hline $\mathrm{b}$ & From 1.5 to $3.0 \mathrm{~m}$ depth & $\mathrm{m}^{3}$ & 4.71 & 95.50 & 449.81 \\
\hline \multicolumn{2}{|c|}{ Total (A) } & & & & 836.03 \\
\hline 2 & Carting of boring set & Job & 1 & 300.00 & 300.00 \\
\hline \multirow[t]{2}{*}{3} & Drilling charges (lined) & $\mathrm{m}$ & 24 & 307.15 & 7371.60 \\
\hline & (Unlined) & $\mathrm{m}$ & 6 & 307.15 & 1842.90 \\
\hline \multicolumn{2}{|c|}{ Total (B) } & & & & 9514.50 \\
\hline 4 & Materials detail & & & & \\
\hline a & $110 \mathrm{~mm}$ PVC pipe $\left(6 \mathrm{Kgf} / \mathrm{cm}^{2}\right)$ & $\mathrm{m}$ & 24 & 149.00 & 3576.00 \\
\hline $\mathrm{b}$ & $110 \mathrm{~mm}$ FTP with cast iron flange & Unit & 3 & 120.00 & 360.00 \\
\hline $\mathrm{c}$ & Solvent cement & 1 & 0.1 & 144.00 & 14.40 \\
\hline $\mathrm{d}$ & $100 \mathrm{~mm}$ reflux valve (non ISI) & Unit & 1 & 1140.00 & 1140.00 \\
\hline $\mathrm{e}$ & $100 \mathrm{~mm}$ cast iron bend & Unit & 1 & 510.00 & 510.00 \\
\hline \multicolumn{2}{|c|}{ Total $(\mathrm{C})$} & & & & 5600.40 \\
\hline 5 & Pumping test, (diesel pump set charges) & $\mathrm{h}$ & 20 & 110.00 & 2200.00 \\
\hline \multicolumn{2}{|c|}{ Total (D) } & & & & 2200.00 \\
\hline \multicolumn{2}{|c|}{ Total $(\mathrm{A}+\mathrm{B}+\mathrm{C}+\mathrm{D})$} & & & & $18,150.93$ \\
\hline 6 & Contingency ( $2 \%$ of total) & & & & 363.02 \\
\hline \multicolumn{2}{|c|}{ Grand total (INR) } & & & & $18,513.94$ \\
\hline \multicolumn{2}{|c|}{ SAY (INR) } & & & & $18,500.00$ \\
\hline
\end{tabular}

Table 3 Pattern of assistance under the scheme on the basis of caste and land holding [2]

\begin{tabular}{|c|c|c|c|c|}
\hline $\begin{array}{l}\text { Sl. } \\
\text { no. }\end{array}$ & Name of scheme & Category of beneficiary & $\begin{array}{l}\text { Category of land } \\
\text { holders }\end{array}$ & $\begin{array}{l}\text { Admissible } \\
\text { subsidy }\end{array}$ \\
\hline \multirow[t]{8}{*}{1} & Free boring (shallow tube well) & & & \\
\hline & \multirow[t]{3}{*}{ (i) For boring } & \multirow[t]{2}{*}{ General } & Small & $\begin{array}{l}\text { Up to INR } \\
5000 /-\end{array}$ \\
\hline & & & Marginal & $\begin{array}{l}\text { Up to INR } \\
7000 /-\end{array}$ \\
\hline & & Schedule caste/schedule tribe & Small/marginal & $\begin{array}{l}\text { Up to INR } \\
10,000 /-\end{array}$ \\
\hline & \multirow[t]{3}{*}{ (ii) For pump set } & \multirow[t]{2}{*}{ General } & Small & $\begin{array}{l}\text { Up to INR } \\
4500 /-\end{array}$ \\
\hline & & & Marginal & $\begin{array}{l}\text { Up to INR } \\
\text { 6000/- }\end{array}$ \\
\hline & & Schedule caste/schedule tribe & Small/marginal & $\begin{array}{l}\text { Up to INR } \\
\text { 9000/- }\end{array}$ \\
\hline & $\begin{array}{l}\text { (iii) High density polyethylene pipe irrigation system ( } 25 \% \text { of } \\
\text { beneficiary) }\end{array}$ & $\begin{array}{l}\text { General/schedule caste/ } \\
\text { schedule tribe }\end{array}$ & Small/marginal & $\begin{array}{l}\text { Up to INR } \\
\text { 3000/- }\end{array}$ \\
\hline
\end{tabular}

bore well and hands over the bore well to the farmer for operation and maintenance. If the cost of boring is more than above assistance, the additional expenditure is borne by the farmer. Table 4 presents the increase in irrigated area with increase in the number of bore wells from the year 1984-1985 to 2013-2014 [1, 3].

The adaption of the presented indigenous drilling technique has boost up the pace of tube well construction in the 
Table 4 Cumulative progress of shallow boring and irrigated area [1, 3]

\begin{tabular}{|c|c|c|}
\hline Year & No. of boring & Net irrigated area (in lakh hect.) \\
\hline $1984-1985$ & 5481 & 101.54 \\
\hline $1985-1986$ & 59,927 & 101.55 \\
\hline 1986-1987 & $1,20,434$ & 98.54 \\
\hline $1987-1988$ & $1,85,055$ & 100.43 \\
\hline 1988-1989 & $3,54,317$ & 101.69 \\
\hline $1989-1990$ & $5,40,482$ & 103.32 \\
\hline 1990-1991 & $7,39,062$ & 105.42 \\
\hline 1991-1992 & $9,37,854$ & 110.48 \\
\hline $1992-1993$ & $11,30,039$ & 113.22 \\
\hline 1993-1994 & $13,24,136$ & 115.64 \\
\hline 1994-1995 & $15,98,881$ & 116.70 \\
\hline $1995-1996$ & $18,84,001$ & 117.47 \\
\hline 1996-1997 & $21,68,832$ & 119.99 \\
\hline $1997-1998$ & $22,03,184$ & 120.12 \\
\hline 1998-1999 & $23,04,435$ & 126.91 \\
\hline 1999-2000 & $23,44,470$ & 124.70 \\
\hline $2000-2001$ & $24,20,242$ & 124.01 \\
\hline 2001-2002 & $25,01,999$ & 128.28 \\
\hline $2002-2003$ & $25,76,612$ & 128.48 \\
\hline 2003-2004 & $26,64,527$ & 132.27 \\
\hline 2004-2005 & $28,04,484$ & 131.19 \\
\hline 2005-2006 & $30,11,232$ & 130.75 \\
\hline 2006-2007 & $32,32,364$ & 133.13 \\
\hline 2007-2008 & $34,91,171$ & 130.85 \\
\hline 2008-2009 & $36,52,160$ & 134.35 \\
\hline 2009-2010 & $37,39,192$ & 133.83 \\
\hline 2010-2011 & $39,10,575$ & 134.40 \\
\hline 2011-2012 & $40,84,359$ & 138.09 \\
\hline 2012-2013 & $42,20,600$ & 139.29 \\
\hline 2013-2014 & $43,12,700$ & 140.27 \\
\hline
\end{tabular}

Unit: 10 lakh hectare $=1$ million hectare

state. In the first 6 years from the start of scheme in year 1984-1985, only 0.54 million bore wells were constructed and the net irrigated area in the state increased by only 0.178 million hectares. However, with the introduction of new drilling technology, 1.34 million bore wells were constructed during the period 1990-1991 to 1995-1996 [3] and the net irrigated area was increased by 1.45 million hectares [1]. Thus, it can be concluded that the mass adaption of innovative drilling technology along with the subsidy have played a pivotal role in increasing the irrigated area in the state.

\section{Conclusion}

With the adaption of the innovative indigenous drilling technique, it could be possible to construct a large number of bore wells in cheaper rates and in relatively short time. The resulting increase in the irrigated area has led to increase in crop production which has changed the life of millions of small and marginal farmers of the state. This innovative technology is cost effective and can be used to rapidly drill shallow bore wells in alluvial formations. 


\section{References}

1. Government of Uttar Pradesh, Year wise Statistical Diaries (Economic and Statistics Division, State Planning Institute, Uttar Pradesh, Lucknow, 1985-2015)

2. Government of Uttar Pradesh, Guide-Lines of Free Boring Scheme (Department of Minor Irrigation, Lucknow, 2012)

3. Government of Uttar Pradesh, Year wise Progress Report of Free Boring Scheme (Department of Minor Irrigation, Uttar Pradesh, Lucknow, 1984-1985 to 2015-2016)
4. D.K. Todd, Ground Water Hydrology, 2nd edn. (Wiley, New York, 1980), pp. 169-185

5. A.M. Michael, Irrigation Theory and Practices, 1st edn. (Vikas Publishing House Pvt. Ltd., New Delhi, 1978), pp. 141-166

6. Government of Uttar Pradesh, Report on "Pressure Boring Set" (Department of Minor Irrigation, Lucknow, 1992)

7. Government of Uttar Pradesh, Model Estimates of Cavity and Strainer Boring (2016-2017) (Department of Minor Irrigation, Lucknow, 2017) 